\title{
Ectopic adrenal gland tissue in the inguinal hernia sac occuring in an adult
}

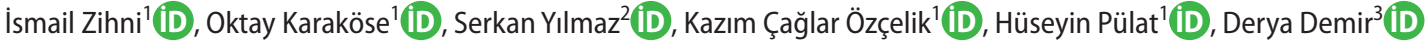 \\ ${ }^{1}$ Department of General Surgery, Suleyman Demirel University, School of Medicine, Isparta, Turkey \\ ${ }^{2}$ Clinic of General Surgery, Manisa State Hospital, Manisa, Turkey \\ ${ }^{3}$ Clinic of Pathology, Manisa State Hospital, Manisa, Turkey
}

\section{ABSTRACT}

Ectopic adrenal tissue is a benign lesion generally determined incidentally during a surgical intervention applied for another reason. This tissue may be present along the path of the testicles and groin discovered during surgery. While the condition has been mainly reported in the pediatric population, it is very rarely reported in adults. The aim of this study was to present an adult patient with ectopic adrenal tissue which was determined incidentally within an indirect inguinal hernia sac.

Keywords: Adrenal glands, ectopic tissue, hernia sac, adult

Cite this article as: Zihni I, Karaköse O, Yılmaz S, Özçelik KÇ, Pülat H, Demir D. Ectopic adrenal gland tissue in the inguinal hernia sac occuring in an adult. Turk J Surg 2020; 36 (3): $321-323$

\section{Corresponding Author}

İsmail Zihni

E-mail: ismailzihni@gmail.com

Received: 24.06 .2015

Accepted: 21.01.2016

Available Online Date: 28.09 .2020

O Copyright 2020 by Turkish Surgical Society Available online at www.turkjsurg.com

DOI: $10.47717 /$ turkjsurg.2020.3255

\section{INTRODUCTION}

The observation of adrenal tissue ectopically in other localizations was first described by Morgagni in 1740 (1). Currently, majority of the cases of ectopic adrenal tissue are known to be encountered in the retroperitoneal area, the kidney parenchyma, the celiac plexus, thorax, liver capsule, lungs brain and less often in the spermatic cord, testis and the surrounding tissues (2). In the literature, it has been noted that the majority, primarily in the pediatric age group, are determined incidentally during surgery $(1,3)$. In contrast to the literature, the case presented here is 35 years old. In this age, ectopic adrenal tissue is very rarely seen in the location of an inguinal hernia sac.

\section{CASE REPORT}

A 35-year-old male presented with complaints of pain and swelling in the right inguinal area. From anamnesis, it was learned that the complaints had been ongoing for approximately 5 years and the pain and swelling increased when undertaking strenuous labor. There was nothing remarkable in the patient history, and physical examination determined a right-sided inguinal hernia. The decision was taken to operate on the patient, who was informed on the surgical technique and a written informed consent form was received. With this diagnosis, the patient was admitted for surgery, and in the exploratory operation, it was seen that there was an indirect inguinal hernia and within the hernia sac, a yellow-colored mass of approximately $5 \mathrm{~mm}$. The hernia was excised together with the sac, and Lichtenstein herniorrhaphy was applied. No complications developed and the patient was discharged on postoperative day 1. The histopathologic examination of the mass was reported as ectopic adrenal tissue (Figure 1).

\section{DISCUSSION}

The observation of accessory adrenal tissue around the gonads distant to its own original location is related to the embryogenesis of the gland. The adrenal cortex and medulla originate from separate embryological tissues. While the cortex originates from the coelomic mesodermal epithelium, at between 7-8 weeks of embryogenesis, ectodermal cells of the neural cleft separate from the celiac plexus and advance into the primordial cortex. Thus, the medulla section of the adrenal 


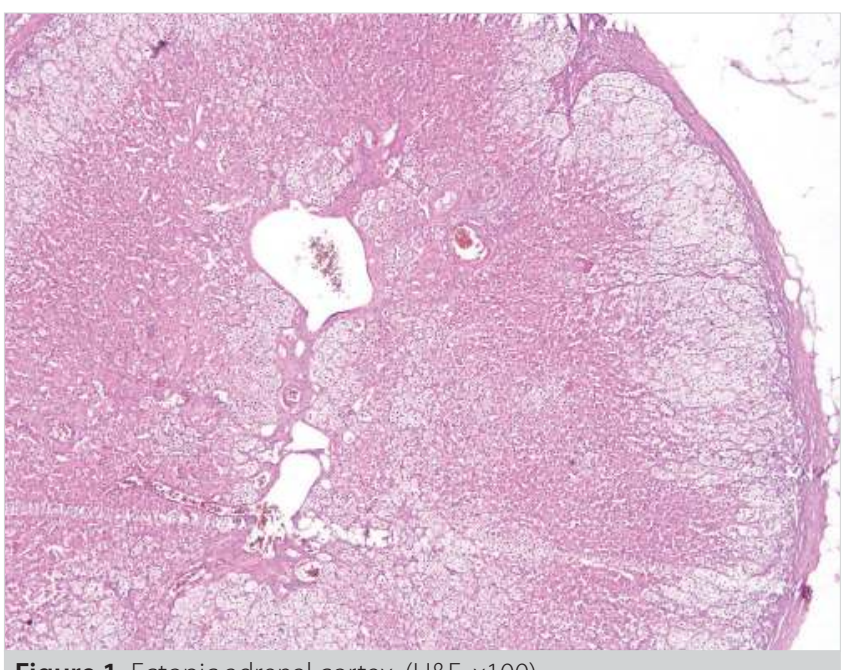

Figure 1. Ectopic adrenal cortex. (H\&E, x100).

gland develops. Aberrant adrenal glands or accessory adrenals form between this $7^{\text {th }}$ and $8^{\text {th }}$ week. They develop in the form of multiple primordial or separately secondary to the main gland. If they are close to the main gland, they include the medulla $(1,4)$. Therefore, the majority of ectopic adrenal tissues seen in the spermatic cord or the epididymis are formed from the cortex section only. Consistent with these studies, in histopathologic examination, only the cortex layer of the ectopic adrenal tissue was in the specimen (Figure 1).

Extra-adrenal tissue is seen at a rate of $3 \%$ in children in inguinal region operations and at 7.5-15\% in the testis region of newborns. In inguinal region operations, extra-adrenal tissue is more often encountered together with undescended testis than in inguinal hernia $(5,6)$.

Ectopic adrenal tissue within an inguinal hernia sac, as in the current case, is rarely seen in adults. The reason for this is that over time, ectopic adrenal tissue becomes atrophied (1). In their search in the English literature, Mendez et al. (3) have found 117 reported cases in infants and children and only 25 cases in adults. Adrenal ectopia at this site is encountered mainly in males $(3,5,7)$ and very rarely in females where the ectopic tissue lies in a paraovarian location (8).

Ectopic adrenal tissue is known to be benign. In majority, nodules are 1-5 mm in diameter, round and yellow in color. The ectopic adrenal tissue can potentially undergo hyperplasia and neoplasia. In some studies, it has been reported that these nodules can transform to the pheochromocytoma, Leydig cell tumor or adrenal adenoma. Therefore, surgical resection is advisable whenever incidentally found $(1,7,9)$. Furthermore, it has been reported in the literature that compensatory hypertrophy and re-function may be seen after adrenalectomy performed for Cushing (2).

\section{CONCLUSION}

Ectopic adrenal tissue is usually found during inguinal surgery in pediatric patients. Since it may undergo progressive atrophy over time, it is rarely encountered in the adult age group. If yellow millimetric nodules are detected during inguinal surgery, ectopic adrenal tissue should be considered in differential diagnosis, and it should be excised for histopathologic analysis since it is accepted as one of possible cause of malignancy.

Informed Consent: Written informed consent was obtained from patient who participated in this case.

Peer-review: Externally peer-reviewed.

Author Contributions: Concept - I.Z., S.Y., O.K., D.D.; Design - I.Z., O.K., S.Y.; Materials - D.D., S.Y., IZ.; Data Collection and/or Processing - O.K., K.Ç.Ö, H.P., D.D.; Literature Search - H.P., K.Ç.Ö., I.Z.; Writing Manuscript - I.Z.; Critical Reviews - H.P., K.Ç.Ö.

Conflict of Interest: No conflict of interest was declared by the authors.

Financial Disclosure: The authors declared that this study has received no financial support.

\section{REFERENCES}

1. OğuzF, Yıldız T, Beytur A, Söylemez H, AltıntaşR, Şamdancı E, et al. Evaluation of children with inguinoscrotal ectopic adrenal tissues. Turk J Med Sci 2013; 43: 553-6. [CrossRef]

2. Usta U, Türkmen E, Aydın NE. Adrenal ectopia within the wall of an ovarian serous cystadenoma. Balkan Med J 2006; 23: 95-8. [CrossRef]

3. Mendez R, Tellado MG, Somoza I, Liras J, Sanchez-Abuin A, Pais E, et al. Ectopic adrenal tissue in the spermatic cord in pediatric patients: surgical implications. Int Braz J Urol 2006; 32: 202-7. [CrossRef]

4. Moore KL. The developing human: clinically oriented embryology. 4 ed. Philadelphia: WB Saunders; 1988. [CrossRef]

5. Sullivan JG, Gohel M, Kinder RB. Ectopic adrenocortical tissue found at groin exploration in children: incidence in relation to diagnosis, age and sex. BJU Int 2005; 95: 407-10. [CrossRef]

6. Okur H, Küçükaydın M, Kazez A, Kontaş O. Ectopic adrenal tissue in the inguinal region in children. Pediatr Pathol Lab Med 1995; 15: 763-7. [CrossRef]

7. Ketata S, Ketata H, Sahnoun A, FakhFakh H, Bahloul A, Mhiri MN. Ectopic adrenal cortex tissue: An incidental finding during inguinoscrotal operations in pediatric patients. Urol Int 2008; 81: 316-9. [CrossRef]

8. Verdonk C, Guerin C, Lufkin E, Hodgson SF. Activation of virilizing adrenal rest tissues by excessive ACTH production. An unusual presentation of Nelson's syndrome. Am J Med 1982; 73: 455-9. [CrossRef]

9. Rabie ME, Shah MT, Jamil S, Al-Shraim MM. Adrenal rests associated with ectopic testis in an adult: Clinical significance. Urol Ann 2013; 5: 302-4. [CrossRef] 


\section{OLGU SUNUMU-ÖZET}

Turk J Surg 2020; 36 (3): 321-323

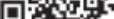

\section{Yetişkin bir hastada inguinal herni kesesinde görülen ektopik adrenal bez dokusu}

İsmail Zihni' ${ }^{1}$ Oktay Karaköse' ${ }^{1}$, Serkan Yılmaz ${ }^{2}$, Kazım Çağlar Özçelik ${ }^{1}$, Hüseyin Pülat' ${ }^{1}$ Derya Demir ${ }^{3}$

${ }^{1}$ Süleyman Demirel Üniversitesi Tıp Fakültesi, Genel Cerrahi Anabilim Dalı, Isparta, Türkiye

${ }^{2}$ Manisa Devlet Hastanesi, Genel Cerrahi Kliniği, Manisa, Türkiye

${ }^{3}$ Manisa Devlet Hastanesi, Patoloji Kliniği, Manisa, Türkiye

\section{ÖZET}

Ektopik adrenal doku genellikle başka bir amaçla yapılan cerrahi girişimlerde tesadüfen saptanan benign bir lezyondur. Bu lezyon kasık cerrahisi sırasında, testislerin iniş yolu boyunca fark edilebilir. Bu durum genellikle çocuk hastalarda görülmekle birlikte; çok nadir olarak yetişkinlerde bildirilmektedir. Biz bu çalışmamızda; yetişkin bir hastada, indirekt inguinal fıtık kesesi içinde tesadüfen saptanan, ektopik adrenal doku olgusunu sunduk.

Anahtar Kelimeler: Adrenal bez, ektopik doku, fıtık kesesi, yetişkin

Doi: $10.47717 /$ turkjsurg. 2020.3255 